\title{
LOW LEVEL OF ISOENZYME VARIATION IN AN ISLAND POPULATION OF JUNIPERUS OXYCEDRUS SUBSP. MACROCARPA (SM. EX SIBTH.) BALL.
}

\author{
ANDRZEJ LEWANDOWSKI, ADAM BORATYŃSKI, LEON MEJNARTOWICZ \\ Polish Academy of Sciences, Institute of Dendrology, \\ 62-035 Kórnik, Poland
}

(Received: February 14, 1996. Accepted: June 1, 1996)

\begin{abstract}
The isoenzyme variation in a geographically well isolated population of Juniperus oxycedrus subsp. macrocarpa from Korfu island was investigated. Based on the 18 putative isoenzyme loci a very low level of variation has been observed. In the studied material only $11 \%$ (95\% criterion) of the loci were polymorphic. The number of alleles per locus was 1.17 and the observed, and expected heterozygosities were 0.016 , and 0.024 , respectively.
\end{abstract}

KEY WORDS: Juniperus oxycedrus subsp. macrocarpa, isoenzymes, genetic variation.

\section{INTRODUCTION}

Juniperus oxycedrus subsp. macrocarpa is a coastal species, with disjunctive, circum-Mediterranean range in S Europe, NW Africa and SW Asia (Fig. 1A), (Franco 1963, Jalas and Suominen 1973, Greuter et al. 1984, Boratyński et al. 1992). J. macrocarpa had been previously described as a separate species by Smith in 1813 from Greece. It differs from $J$. oxycedrus L. known earlier from France, with their cones larger and longer than needles. Juniperus oxycedrus and $J$. macrocarpa are mediterranean species and were mistaken one for another. Recently J. macrocarpa is considered as a subspecies of J. oxycedrus s.l. (Franco 1963, 1964, Code and Cullen 1965, Jalas and Suominen 1973, Greuter et al. 1984, Lebreton et al. 1991).

Not fully clear taxonomical status of taxons included into $J$. oxycedrus s.l. and a complex of characters of this species promoted us to investigate their genetic arrangement. The first results of isoenzyme variation of $J$. oxycedrus subsp. macrocar$p a$ from the island Korfu are presented below.

\section{MATERIAL AND METHODS}

The studied material comes from a natural locality of J. oxycedrus subsp. macrocarpa from island Korfu in Greece (Fig. 1B). Cones were collected from 21 specimens (trees or clump of trees) growing on dunes in SW part of the island, on the sand-bar between Ionian Sea and Korission Lake (Fig. 1C and 2) in May 1995. Only a few trees of J. oxycedrus subsp. macrocarpa were fructifying in 1995 . To gather a population of 21 specimens more than 300 specimens had to be reviewed. Only eight macrogametophyte from each of the 21 trees were utilized to define genotypes of the trees.
Analyses were performed using macrogametophyte tissue from dry seeds. The following 11 enzyme systems were analyzed (their abbreviations, enzyme commission numbers and buffer systems used for electrophoresis in parentheses): fluorescent esterase (FLE, EC 3.1.1.1., I), glutamate dehydrogenase (GDH, EC 1.4.1.2., I), glutamate-oxaloacetate transaminase (GOT, EC 2.6.1.1., I), isocitrate dehydrogenase (IDH, EC 1.1.1.42., II), leucine aminopeptidase (LAP, EC 3.4.1.1., I), malate dehydrogenase (MDH, EC 1.1.1.37., II), menadione reductase (MNR, EC 1.6.99.2, II), phosphoglucose isomerase (PGI, EC 5.3.1.9., I), phosphoglucomutase (PGM, EC 2.7.5.1., I), sorbitol dehydrogenase (SRDH, EC 1.1.1.14., I), superoxide dismutase (SOD, EC 1.15.1.1., I). Isoenzyme separation was carried out in $12 \%$ starch gels, in two different buffer systems. System I according to Ridgeway et al. (1970), and system II after Siciliano and Shaw (1976). Staining procedures for all enzymes followed Cheliak and Pitel (1984).

Genetic variability was described by the average number of alleles per locus $(\mathrm{Na})$, the percent of polymorphic loci $(\mathrm{P})$, observed (Ho) and expected (He) heterozygosities (Nei 1975).

\section{RESULTS AND DISCUSSION}

Analysis of 11 enzyme systems in 21 trees revealed the 18 putative loci: Fle1, Gdh, Got1, Got2, Idh1, Idh2, Lap1, Lap2, Mdh1, Mdh2, Mdh3, Men1, Pgi1, Pgi2, Pgm1, Sod1, Sod2, Srdh. A low level of allozyme variation was observed in our material. We found only four heterozygous trees. Two of them were double heterozygous at Pgi2 and Fle1, and Pgi2 and Lap1 loci, respectively. Another two trees were heterozygous at locus Lap1. Additionally, two trees were rare homozygotes at Lap1 and Pgi2 loci. At each of the three variable loci (Fle1, Lap1 and Pgi2) we found only two alleles, in- 


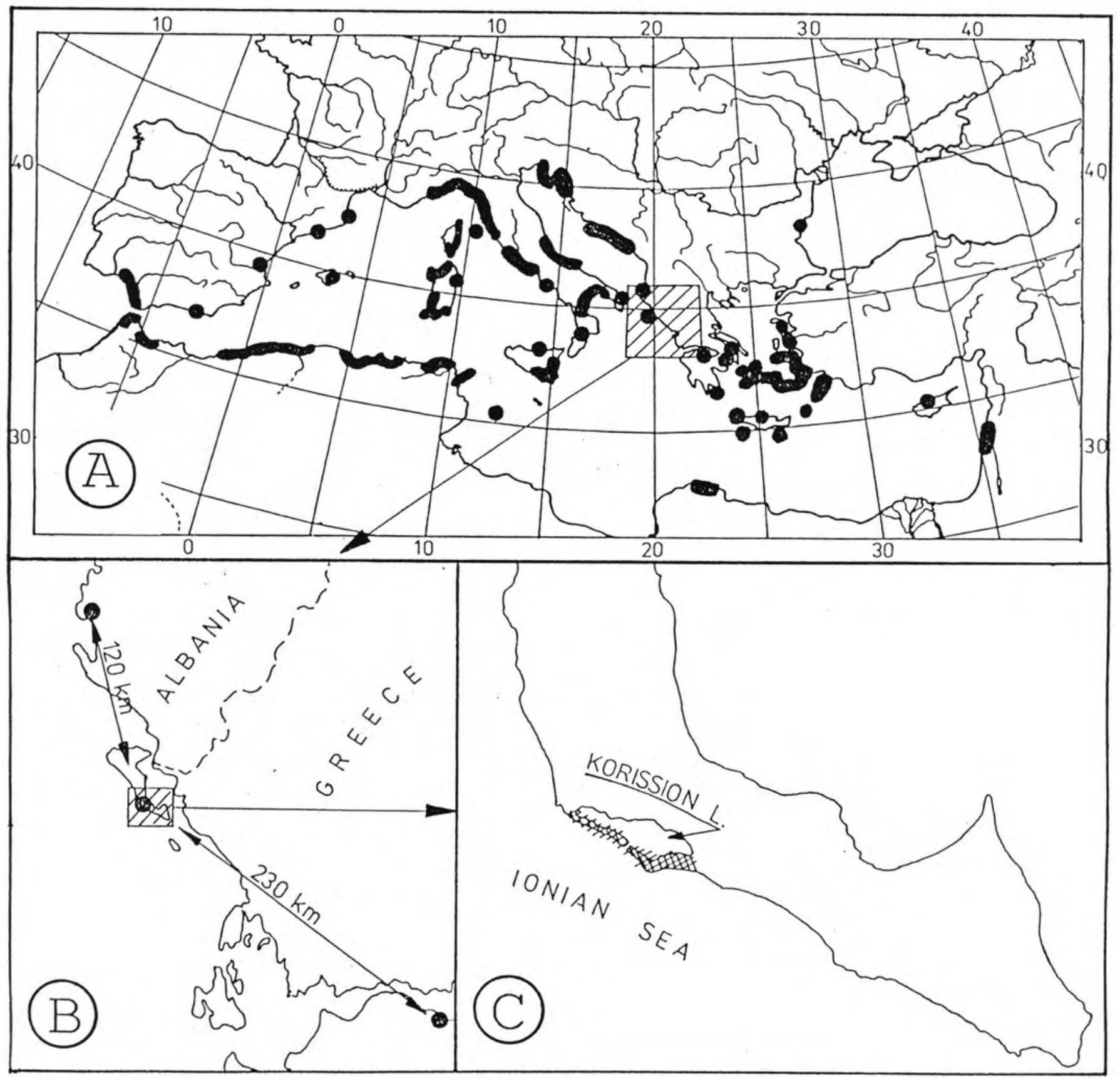

Fig. 1. A - distribution of Juniperus oxycedrus subsp. macrocarpa (after Jalas and Suominen 1973, changed and supplemented); B - distances between Korfu island and nearest localities of J. oxycedrus subsp. macrocarpa; C - situation of studied population of J. oxycedrus subsp. macrocarpa on the island of Korfu.

cluding null allele at Lap1 locus. Because of the small number of seeds from heterozygous trees the Mendelian inheritance at three detected variable loci has not been tested.

If our interpretation of zymograms, concerning 18 putative loci was correct, electrophoretic assessments of genetic diversity for J. oxycedrus subsp. macrocarpa in the Korfu island revealed that only $11 \%$ ( $95 \%$ criterion) of the loci assayed are polymorphic. The number of alleles per locus is 1.17 , and the $\mathrm{Ho}$ and $\mathrm{He}$ are 0.016 , and 0.024 , respectively. Level of isoenzyme variation detected in the presented paper was low and was one of the lowest, detected so far for European tree species (Müller-Starck et al. 1992).

On the base of the obtained results it is hard to explain the real reason of the low level of isoenzyme variation observed in population of J. oxycedrus subsp. macrocarpa from Korfu.
A low level of isoenzyme variation within coniferous tree species is rather uncommon (Loveless and Hamrick 1984, Müller-Starck et al. 1992). Such factors as outcrossing, windpollination, seed dispersal by wind, wide continuous ranges, high population density and large effective size allows to maintain a large amount of genetic variability in conifers (Loveless and Hamrick 1984). Not all of these factors are typical for investigated in this paper species. J. oxycedrus subsp. macrocarpa is a species with incontinuous geographical range. Species with such kind of distribution were frequently reported to have a small intrapopulation variation (Hamrick et al. 1992).

The observed by us positive mean fixation index of 0.17 indicates that there is a slight excess of trees with a greater than expected proportion of homozygous loci. These indicates that 


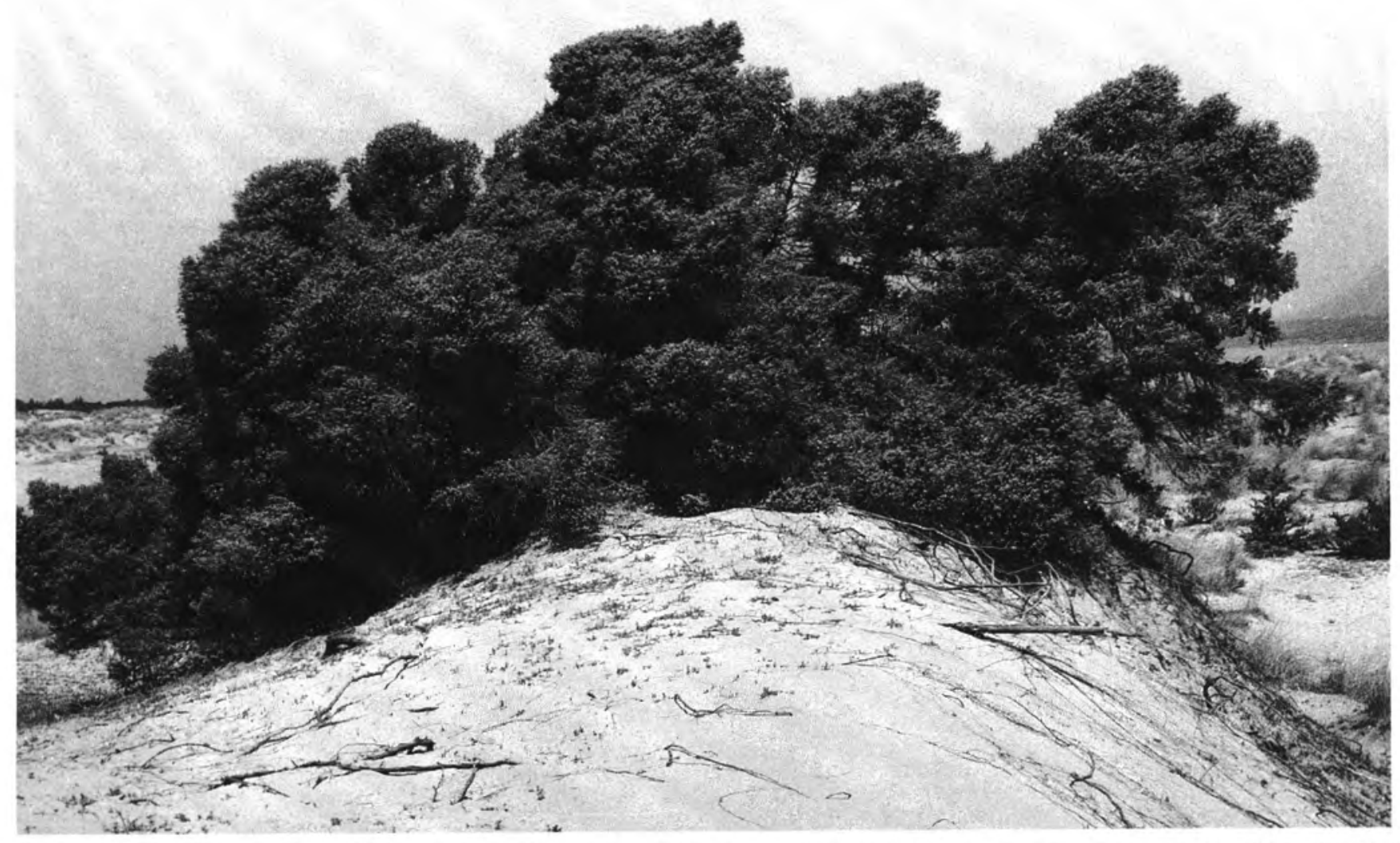

Fig. 2. Specimen of Juniperus oxycedrus subsp. macrocarpa forming a clump on top of the dune on a sandy-bar between the Ionian Sea and Korission Lake (phot. A. Boratyński).

inbreeding may be one of the most important factors in reducing genetic variability in geographically isolated population from Korfu. On the other hand, the observed low level of isoenzyme variations may reflects the small level of isoenzyme variation of J. oxycedrus subsp. macrocarpa in all Mediterranean region, similarly to Pinus brutia (Schiller et all. 1986).

Additional investigations with great numbers of populations is desirable, not only to explain low level of isoenzyme variation of J. oxycedrus subsp. macrocarpa in the Korfu island, but also to detect the real level of isoenzyme variation in this interesting Mediterranean conifer species.

\section{ACKNOWLEDGMENTS}

We thank Janina Kozłowska and Maria Ratajczak for their laboratory assistance.

\section{LITERATURE CITED}

BORATYŃSKI A., BROWICZ K., ZIELIŃSKI J. 1992. Chorology of trees and shrubs in Greece. Sorus, Poznań-Kórnik. 286p.

CHELIAK W.M., PITEL J.A., 1984. Techniques for starch gel electrophoresis of enzymes from forest tree species. Information Report PI-X-42, Petawawa National Forestry Institute.

COODE M.J.E., CULLEN J. 1965. Juniperus L. In: P.H. DAVIES (ed.). Flora of Turkey, vol. 1: 78-84.

FRANCO J. do A. 1963. Taxonomic Notes on Juniperus oxycedrus L. and J. macrocarpa Sm. Feddes Repert. 68: 163-167.
FRANCO J. do A. 1964. Juniperus L. In: TUTIN T.G., HEYWOOD V.H., BURGES N.A., VALENTINE D.H., WALTERS S.M., WEBB D.A. (eds.) Flora Europaea, vol.1: 38-39. Cambridge, University Press.

GREUTER W., BURDET H.M., LONG G. 1984. Med-Checklist, vol 1. Conserv. Jard. Bot., Ville de Geneve.

HAMRICK J.L., GODT M.W., SHERMAN-BROYLS S.L., 1992. Factors influencing levels of genetic diversity in woody plant species. New Forests 6: 95-124.

JALAS J., SUOMINEN J. 1973. Atlas Florae Europaeae, vol.2. The Committee for Mapping the Flora of Europe and Societas Biologia Fennica Vanamo, Helsinki. 44p.

LEBRETON P., BAYET C., MURACCIOLE M. 1991. The systematic status of Juniperus oxycedrus: a biochemical and biometric approach. Lazaroa 12: 21-42.

LOVELESS M.D., HAMRICK J.L., 1984. Ecological determinants ofgenetic structure in plant populations. Annu. Rev. Ecol. Syst. 15: 65-95.

MÜLLER-STARCK G., BARADAT P.H., BERGMANN F., 1992. Genetic variation within European tree species. New Forests 6: 2347.

NEI M., 1975. Molecular population genetics and evolution. Holland Press, Amsterdam.

RIDGEWAY G.J., SHERBURNE S.W., LEWIS R.D., 1970. Polymorphism in the esterases of Atlantic herring. Trans. Am. Fish. Soc. 99: 147-151.

SCHILLER G., CONKLE M.T., GRUNWALD C., 1986. Local differentiation among Mediterranean populations of Aleppo pine in their isoenzymes. Silvae Genet. 35: 11-19.

SICILIANO M.J., SHAW C.R., 1976. Separation and visualization of enzymes on gels. Chromatographic and electrophoretic techniques. Heinemann, London: 185-209. 


\section{NISKI POZIOM IZOENZYMOWEJ ZMIENNOŚCI \\ W WYSPOWEJ POPULACJI JUNIPERUS OXYCEDRUS SUBSP. MACROCARPA.}

\section{STRESZCZENIE}

Badano poziom zmienności izoenzymowej w izolowanej geograficznie populacji J.oxycedrus subsp. macrocarpa na greckiej wyspie Korfu. Na podstawie analizy domniemanych 18 loci izoenzymowych, stwierdzono bardzo niski poziom zmienności genetycznej analizowanej populacji. W badanym materiale tylko $11 \%$ loci było polimorficzne. Średnia liczba alleli w locus wyniosła 1,17, a heterozygotyczności obserwowana i oczekiwana, odpowiednio: 0.016 i 0.024 .

SŁOWA KLUCZOWE: Juniperus oxycedrus subsp. macrocarpa, izoenzymy, zmienność genetyczna. 